Arch. histol. jap. Vol. 33, No. 3 (1971)

p. $225-246$

Department of Anatomy (Prof. T. FujITA), Niigata University School of Medicine,

Niigata, Japan

\title{
Stereo-fine Structure of the Splenic Red Pulp. \\ A Combined Scanning and Transmission Electron Microscope Study on Dog and Rat Spleen
}

\author{
Masayuki Mryoshi and Tsuneo FujiTA
}

\author{
Received June 15, 1971
}

Summary. Spleens of the dog and rat were thoroughly washed with Ringer solution through the lienal artery and then perfused with buffered glutaraldehyde. Scanning electron microscope (SEM) observation was made on the cut surfaces of the red pulp. Sections of resin embedded tissues of the same specimens were observed under the transmission electron microscope (TEM).

1. The splenic sinus of the dog and rat was lined by a perforated lattice formed by rodlike lining cells and their cytoplasmic processes as observed in the rabbit (Mryoshi, Fujita and Tokunaga, 1970), though distinct species variations in the pattern of the lattice were recognized.

2. A transiting sinus lacking in perforations was found by the SEM to intervene between the sinus and the trabecular vein.

3. The Billroth cord was a labyrinthic meshwork of thin reticular cell processes under the SEM. TEM observation revealed reticular fibers either ensheathed or sandwiched by reticular cell processes.

4. The reticular cells were attached to the walls of the vein and the sinus by their thin cytoplasmic processes ending in a sole-like expansion.

5. On the external surface of the sinus, thin cytoplasmic processes from the reticular cell feet emerged mainly transversely to the lining cells. Every side bridge of the lining cells was thus backed by a reticular cell process. The ring fibers sandwiched by both cellular elements could be seen only by the TEM.

6. Large, spherical macrophages were found by the SEM dispersed in the cordal spaces and fixed by some reticular fibers. One type of macrophage was covered by bubble-like processses, while another by foliate ones.

7. The TEM observation revealed lysosomes of fine granular content in the former type of macrophage, and large, dense granules of lysosomal nature and large ingested cell debris in the latter.

In spite of various attempts to elucidate the architecture of the splenic red pulp, conclusive evidence explaining blood passage through the tissue and the threedimensional fine structures of its cellular elements do not seem to have been published. (cf. TischendoRf, 1969). Our scanning electron microscope (SEM) observations (Mryoshi, Fujita and Tokunaga, 1970) on the perfused spleen in the rabbit revealed that the sinus was lined by a perforated lattice composed of longitudinally extended rod cells and of transverse cytoplasmic processes and that perforations in the lattice were continuous to the spaces among stellate reticular cells of the cord of Billroth.

The findings coincided well with the light microscope observations (MolLIER, 1911; Hartmann, 1930; Stöhr, MöllendorfF and Görțtler, 1963; Bargmann, 1964) that the grid-like structure on the sinus wall in mammals, except in man and the 
monkey (in which previous opinions diverge as to the occurrence of transverse connections of the rod cells), was composed of the cytoplasmic processes of the sinus lining cells.

Ring fibers, reticular fibers in nature, represent one of the important components which should necessarily be referred to as a structural element of the sinus wall. The fibers which are demonstrated with stain techniques, particularly with silver impregnation, are identified under the transmission electron microscope (TEM) as threads of the basement materials (Weiss, 1957; Stoeckenius, 1958). The latter separate the sinus lining cells from the reticular cells and are continuous to the similar structure in the cord. However, the SEM study in the rabbit spleen by the present authors (1970) only visualized the perpendicular attachment of the reticular cell processes to the sinus wall.

Another important aspect of the spleen is the morphological substrate of the reticulo-endothelial system. It is widely accepted that, besides the sinus lining cells and the cordal reticular cells, specialized macrophages of either a fixed or free type develop and achieve a main phagocytic labour of the spleen. Contrary to a widely held view that the macrophages are anchored by reticular fibers (TISCHENDORF, 1969), PICTET and his co-workers (1969) examined sections of the perfused rat spleen under the TEM and maintained that the macrophages were not attached to the reticular fibers. The superficial structure of the macrophages in general has recently been observed under the SEM in peritoneal fluid (CARR et al., 1968; CARR, 1970; HoPE and FRIEND, 1969) and pulmonary exudate (Holma, 1969). However, no SEM study seems to have been made on the macrophage in the tissue in situ.

In the present study, spleens of the dog and rat in which the splenic cords are more developed than in the rabbit (SNOOK, 1950) are subjected to SEM and TEM study in order to elucidate the stereo-fine structure of the cords of Billroth. A special attempt is made to examine the development and distribution of the macrophages in the red pulp. Moreover, observations on the sinus lining cells in the dog and rat are believed to deserve description in comparison with our previous findings in the rabbit, as it has been stressed in light microscopic studies that the lattice patterns of the sinus wall are conspicuously variable among species (MolLIER, 1911; HaRTMANN, 1930).

\section{Materials and Methods}

Spleens of adult dogs (about $8 \mathrm{~kg}$ ) and albino rats (about $350 \mathrm{~g}$ ) were used in the present study.

After peritoneal injection of Nembutal, the blood in the spleen was washed out by the perfusion of warmed Ringer solution through the splenic artery until the organ turned pale, and then perfused with $100 \mathrm{ml}$ (for dog) or $50 \mathrm{ml}$ (for rat) of the fixative. During the perfusion the blood and perfusate flowed out from the splenic vein cut open at the start of the perfusion. After ligation of the splenic vessels, the entire spleen was removed and kept in the fixative for several days at room temperature. The fixative used in the perfusion and immersion was $2.5 \%$ glutaraldehyde adjusted to $\mathrm{pH} 7.4$ with a $0.1 \mathrm{M}$ phosphate buffer containing $50 \mathrm{ppm} \mathrm{CaCl}_{2}$.

The fixed spleens were cut into small tissue cubes $(3 \times 3 \times 5 \mathrm{~mm})$ and their cut surfaces were washed by a gentle jet of $0.1 \mathrm{M}$ phosphate buffer or distilled water. The specimen cubes were dehydrated, dried in air and coated with carbon and gold 
in an evaporator as described elsewhere (Miyoshi, Fujita and Tokunaga, 1970).

Observation and photography were made with a JEOL, JSM-U3 scanning electron microscope. Accelerating voltage used was $5 \mathrm{kV}$.

For TEM observation some of the specimen cubes of the rat spleen prepared for SEM study were immersed in $0.1 \mathrm{M}$ phosphate buffer ( $\mathrm{pH} 7.4$ ) either before or immediately after air-drying, cut into small pieces and post-fixed in buffered $2 \% \mathrm{OsO}_{4}$ for 2 hrs at room temperature. Following dehydration in graded concentrations of alcohol and propyrene oxide, the tissue pieces were embedded in Epon-epoxy resin according to the method of LUFT (1961). Thin sections cut with glass knives on a Porter-Blum microtome were doubly stained with uran and lead (MilloNig, 1961), and observed in a Hitachi HU 125 Ds electron microscope.

\section{Observations}

\section{A. Scanning electron microscopy}

As observed in the rabbit (Miyoshi, Fujita and Tokunaga, 1970), the cut surfaces of the dog and rat spleen revealed under the SEM the sinuses cut open as furrows or caves whose walls were lined by a perforated lattice, and the cords of Billroth as a spongy structure filling up the spaces between the former (Fig. 1, 4, 8). Exposed areas of the cords on the cut surfaces were far wider in these animals than in the rabbit. This coincided with the survey photomicrographs of perfused spleens in the dog and rabbit (Thomas, 1967) and in the rat (Рістет et al., 1969).

The sinuses of the present animals, particularly of the dog, appeared to be cylindrical spaces anastomosed with each other (Fig. 1,8). Besides some furrows with a relatively constant width (about $20 \mu$ ) along their whole length, many round caves were encountered, which represented the cross sections of the sinuses and were generally constant in diameter (about $20 \mu$ ). The elongated shape of the sinus in the present animals seemed to reflect well the "finger-like" sinus in the dog (SNOoK, 1950; ОнтA, 1957) and the "cucumber-like" sinus in the rat (KNISELY, 1936).

The lattice of the sinus wall was composed of longitudinal rods of lining cells and their transverse side bridges (Fig. 2, 3, 4). Compared with belt-like rods in the rabbit, the rods of the dog and rat resembled threads. Their thickness was about $1 \mu$, though greatly varied among rods. Quite thin rods of about a half micron occurred sometimes. On every rod was seen a nuclear portion which was prominently swollen up in a spindle-shape (about $3 \mu$ thick and $10 \mu$ long).

Transverse cytoplasmic processes forming the side bridges were issued at relatively regular intervals of about 2 or $3 \mu$ from the lateral margins of the rods (Fig. 3, 4). They were almost similar in feature and size to the rods from which they originated. Openings delineated by the lateral margin of these longitudinal and transverse components of the lattice were circular or oval. They measured about $2 \mu$ or more in diameter. Therefore, the sinus wall of the present animals, particularly in the dog, looked like a net with large meshes. Only the spindle-shaped perikaryal protrusion on each rod indicated the extension of the cell.

The free surface of the rod cells was quite smooth and the occurrence of prominent microvilli as in the rabbit was not seen. A faint crest suggesting the cellular attachment was noticed on the middle of some side brigdes.

The interconnection between the sinuses and the transition of the sinus to the 
trabecular vein were also observed. The connected sinus was usually represented by a cave on the sinus wall (Fig. 4). Its orifice was outlined by a sharp, semicircular crest on one side, and a gradual subsidence of the wall on the opposite side. The rod cells on the crest were arranged in parallel to the extension of the crest. The cellular arrangement was more clearly observed on such a fortunate cut surface as when a forked sinal space was exposed longitudinally (Fig. 5). The twisted, spinal arrangement and the bifurcation of the rod cell as seen in the rabbit (Miyoshi, Fujita and ToKUNAGA, 1970) could not be recognized in the dog and rat spleens.

At the sinus transiting to a vein were the rod cells laterally in close contact with each other and no opening was seen between them (Fig. 8). The finding of this transiting sinus was different from the description of BuRKe and Simon (1970) who recognized no transitional zone at the sinus-venous connection.

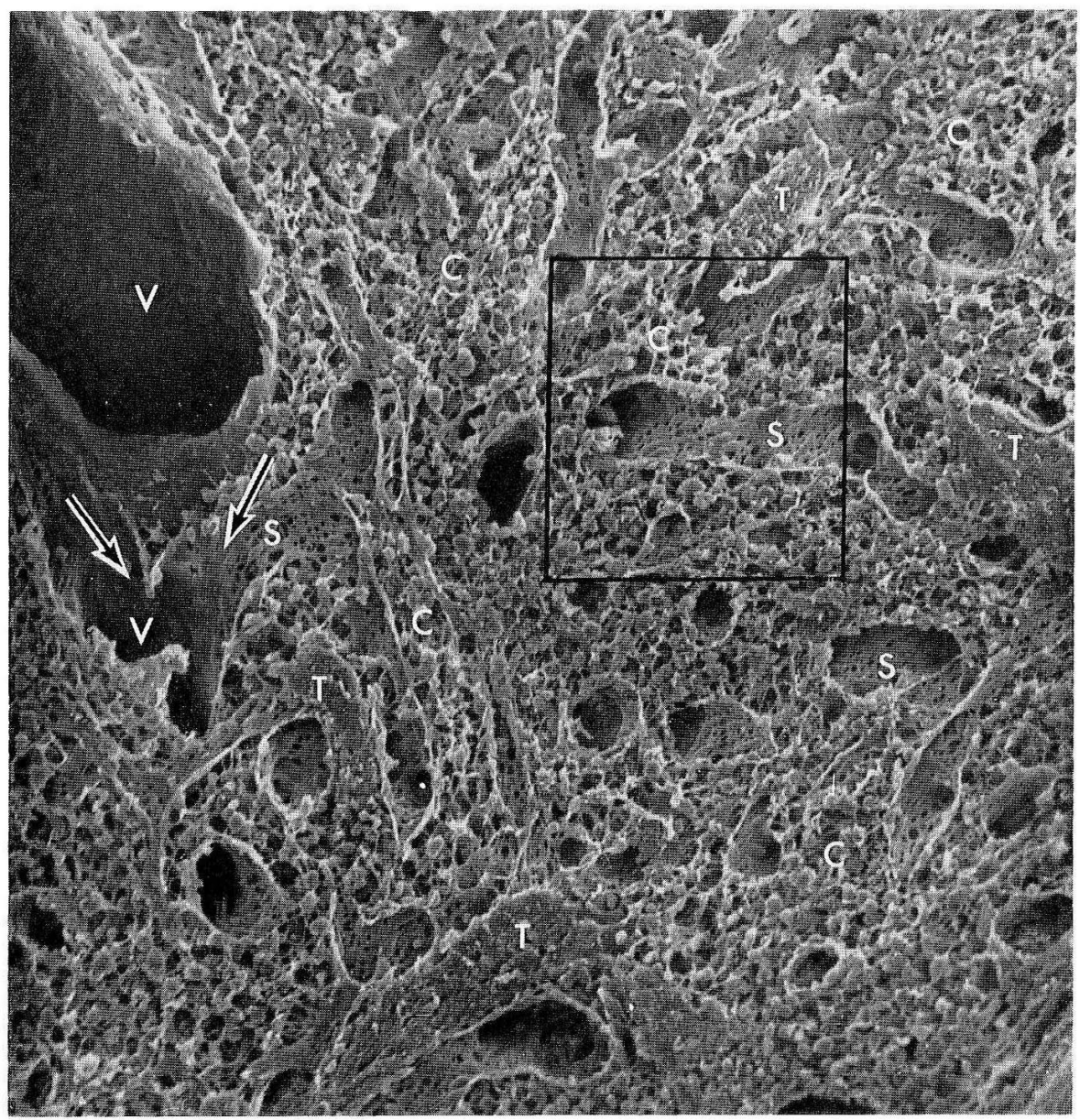

Fig. 1. A low-power scanning electron micrograph of the cut surface of the red pulp of the dog spleen. The sinuses (S) cut open appear as furrows or caves lined by a latticed wall and the cords of Billroth $(C)$ show a spongy profile between the sinuses. At the left, the transition of two sinuses to a travecular vein is seen (arrows). T trabecule. $\times 360$ 
The splenic cord was represented by reticular cells of stellate shape and by the labyrinthic space among them (Fig. 2, 5, 6). The thread-like cytoplasmic processes with which the cells were connected with each other were relatively uniform in size and measured about 200 or $300 \mathrm{~m} \mu$ in thickness. The cytoplasmic threads ramified usually in acute, but sometimes in right angles. Stellate nodes in the cytoplasmic network occurred here and there and some massive nodes likely represented the perikarya of the reticular cells (Fig. 6, 7).

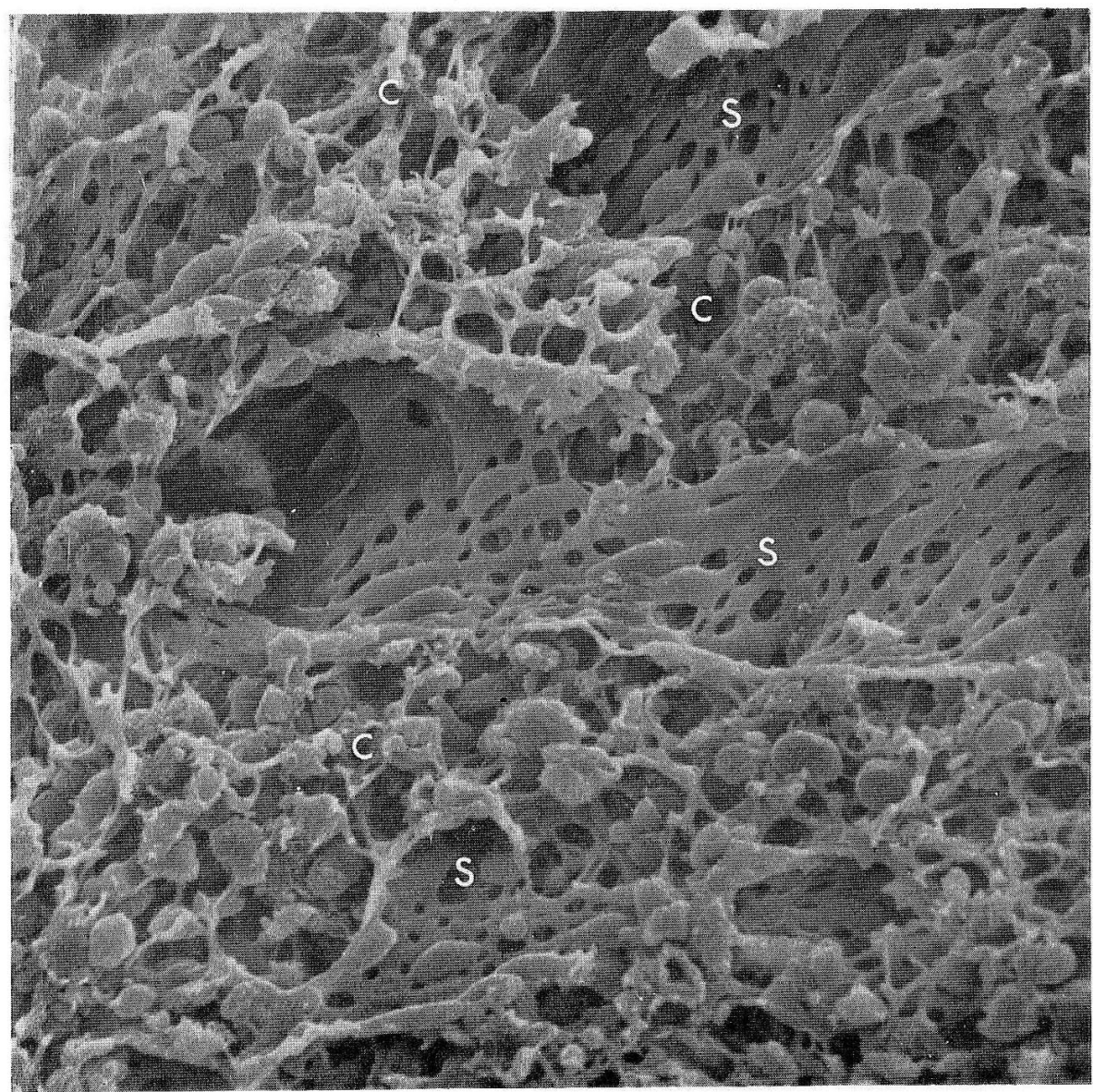

Fig. 2. A closer view of the red pulp in the box in Figure 1. Three sinuses $(S)$ cut open almost longitudinally reveal a typical lattice structure formed by rod cells and their cytoplasmic processes. The cells with spindle-shaped nuclear elevations are extended parallel to the long axis of the sinuses. The splenic cords $(C)$ consist of a loose network of reticular cells. Note the reticular cell processes standing on the wall of the sinus. $\times 1,200$

The free surfaces of the reticular cells were relatively smooth except for some tiny microvilli on the perikaryal portions. High magnification microscopy, however, revealed a longitudinal, wrinkle-like streak on the threads (Fig. 7). Occasional occurrence of two or three streaks was noticed on moderately thick threads or the stellate perikaryal portions. 
Around the sinus and vein the reticular cell processes were extended perpendicularly to their walls to anchor them (Fig. 8, 9). On the outer surface of the sinus, the reticular cell cytoplasm was often flattened and attached to the rod cells (Fig. 11, 12). This foot-like cell portion was stellate in shape and issued some slender cytoplasmic processes (about $200 \mathrm{~m} \mu$ thick) from its margin alongside the sinus wall.

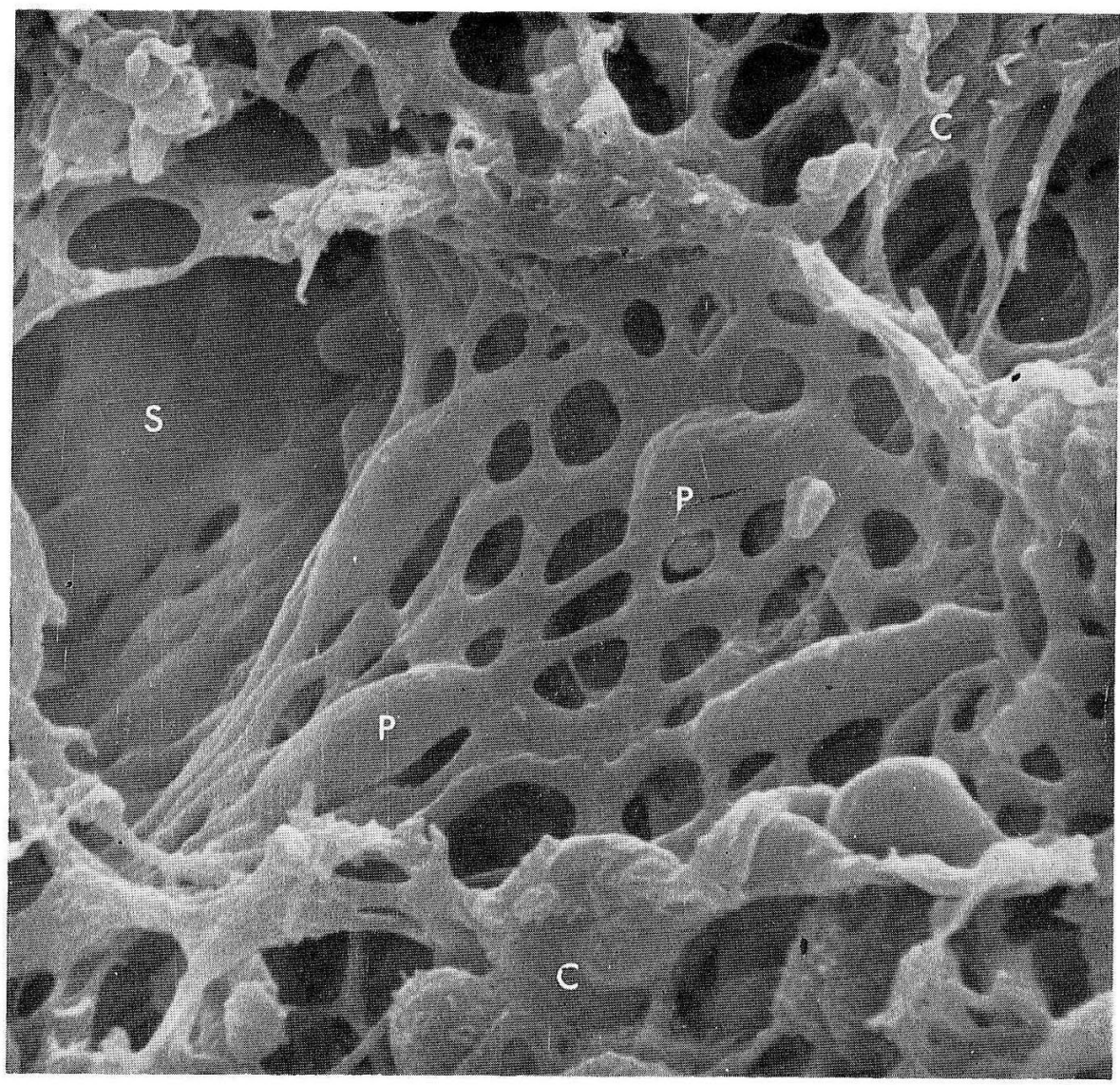

Fig. 3. A typical rectangular lattice pattern in the sinus wall of the dog. Thread-like rod cells with fusiform nuclear swellings $(P)$ extend from the lower left hand corner to the upper right and are connected laterally with neighboring cells by their side processes. $C$ cord of Billroth. $\times 3,700$

The flat processes clinging on the sinus lining cells were discernible by their being slightly thickened. Those processes on the sinus usually extended transversely to the rod and each side bridge of the latter generally was backed by one of the reticular cell processes (Fig. 11, 12), though sometimes membranous cytoplasmic processes ran longitudinally. Rarely seen was a process crossing over the opening of the sinus wall.

Here and there in the meshes of the reticular tissue were seen large, spherical cells (about 10 to $15 \mu$ in diameter) (Fig. 10,11). The occurrence of this type of cell was most prominent in the rat among the animals observed in our previous (MryosHI, 
Fujita and Tokunaga, 1970) and present studies. In the dog most of the round cells bristled with numerous finger-like processes, while some others showed only undulated surfaces (Fig. 6, 9). In the rat two types of cclls could be more clearly discerned (Fig. 10, 11). The one was densely covered with round-headed projections. The other was provided with thin, rather membranous projections and occasionally with relatively long, tongue-like processes.

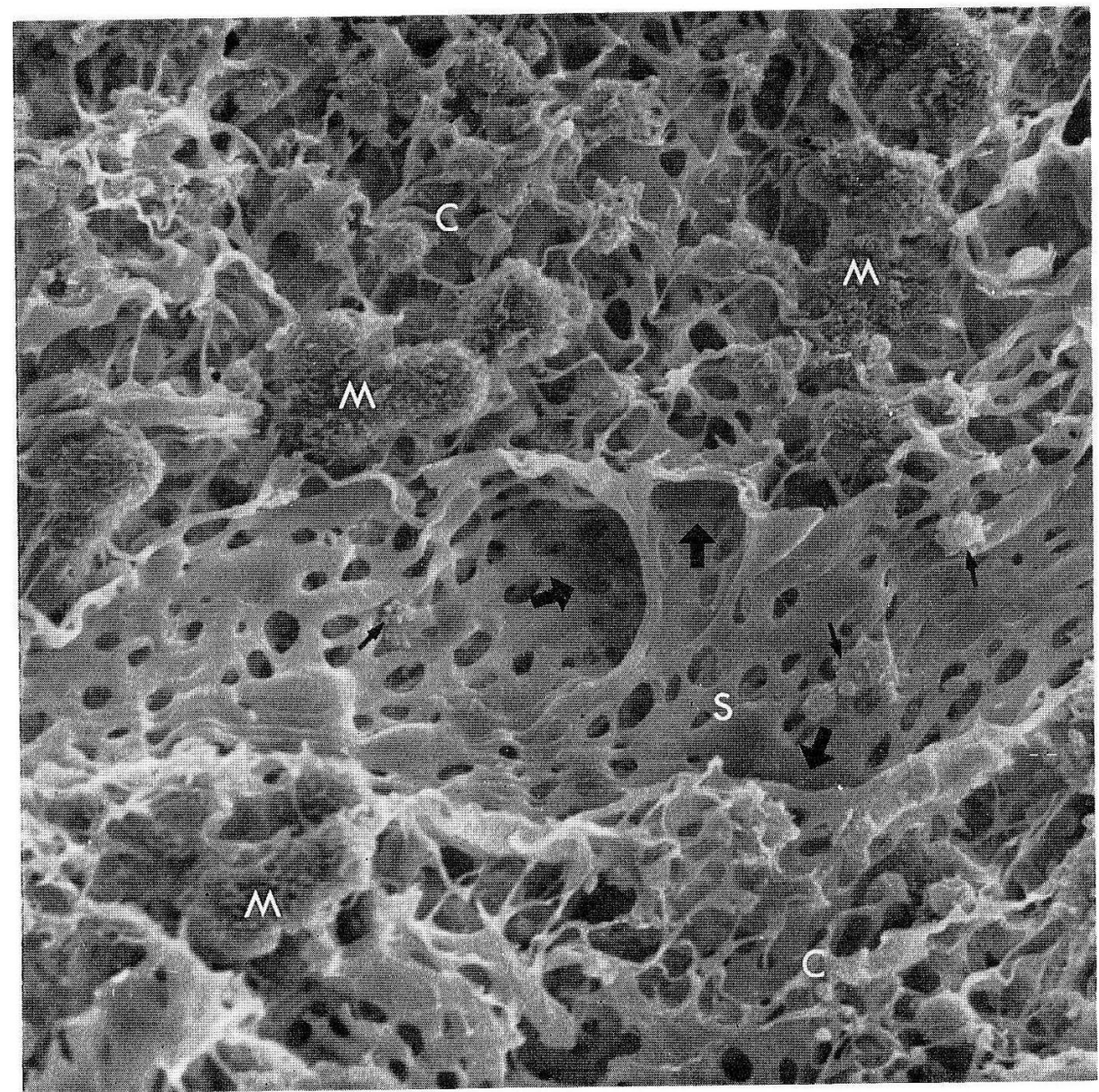

Fig. 4. A scanning electron micrograph of a sinus $(S)$ from the rat splcen cut longitudinally. At the middle of the sinus, three of its branches open (large arrows). Note the rod cells forming a semicircular crest at the branching sites of the sinus. In the cords $(C)$ formed by a network of reticular cells, large, spherical macrophages $(M)$ are seen. The cytoplasm of some macrophages protrudes through the openings in the sinus wall here and there (small arrows) $\times 1,400$

It was clearly seen that some cytoplasmic threads of adjacent reticular cells converged on the round cells (Fig. 11, 12). Furthermore, it was frequently seen that a part of the cell body protruded into the sinus through the opening mentioned above. The extcrnal structure of the cells was quite similar to that of macrophages from peritoneal fluid (CARR et al., 1968; CARR, 1970). 
Round cells of much smaller size and less conspicuous surface structure occurred occasionally in the spaces of the cords. These were supposed to be leucocytes or some other wandering cells such as plasma cells.

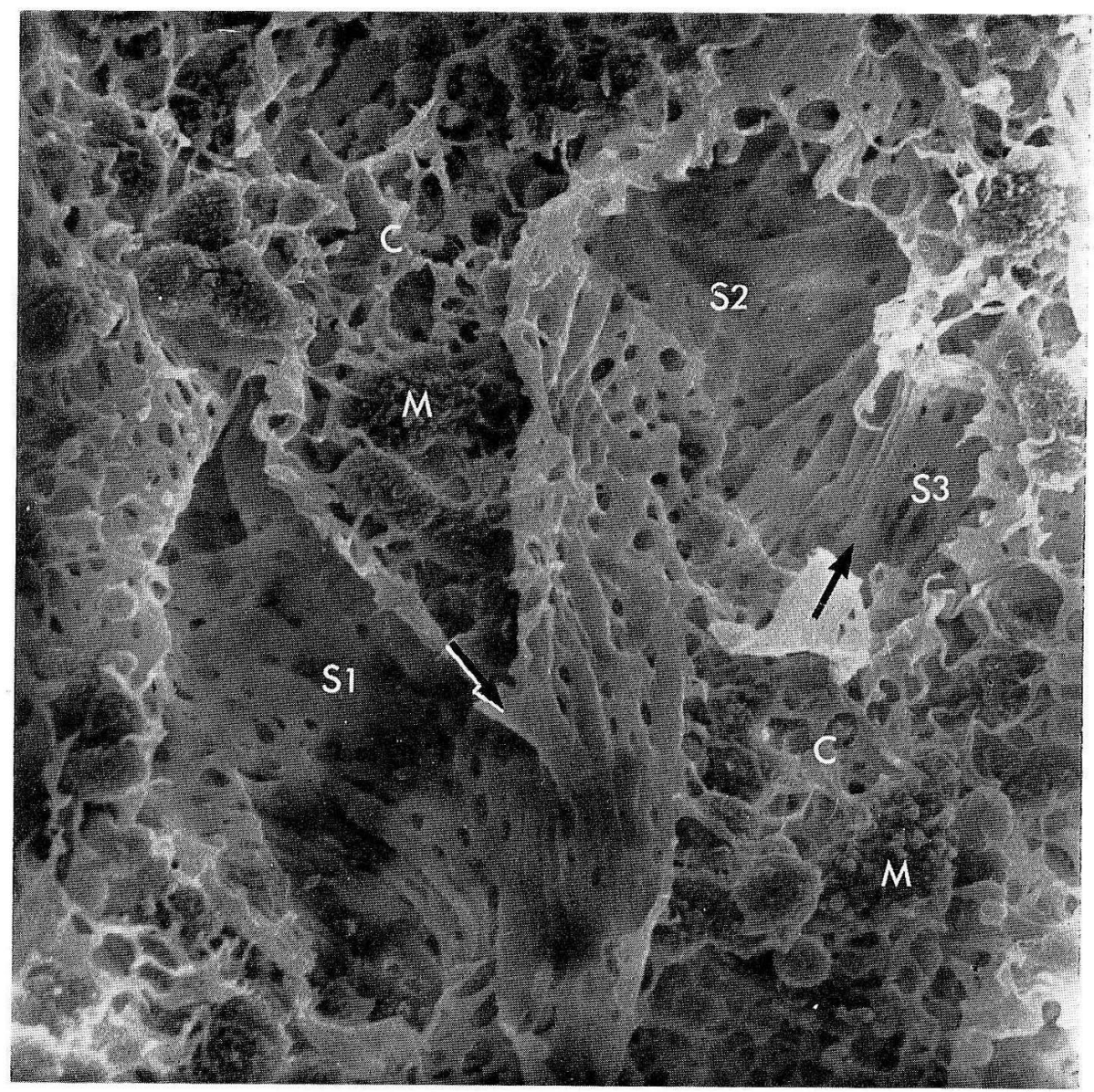

Fig. 5. A scanning electron micrograph of a sinus of the rat forked into three branches $\left(S_{1}, S_{2}\right.$, $S_{3}$ ). The sickle-shaped ridges between the branches (arrows) are formed by a longitudinal bundle of the rods of lining cells. $C$ cords of Billroth, $M$ macrophages. $\times 1,200$

\section{B. Transmission electron microscopy}

The TEM observation in the present study was mainly made for the identification of the structural components of the red pulp. Detailed description will be made on the macrophage in the cord.

Complete removal of the blood from the red pulp clearly showed the fundamental structure of the sinus wall (Fig. 13). The sinus lining cells with variable thickness were arranged in a circular layer in the cross section. Most of the cells were attached laterally to each other, but some interstices were patent. The basal cytoplasm of the sinus lining cells was partly covered by a basement membrane and a cytoplasm of 
the reticular cell in turns, but partly nakedly exposed to the cordal space. The patent interstices between the neighboring sinus lining cells were not covered by the basement membrane or by the reticular cell.

The surface of the sinus lining cells was smooth showing a few pinocytotic invaginations and vesicles. In the cytoplasm lysosomes of smaller size occurred in moderate numbers. One could see no debris of phagocytosed cells such as erythrocytes in the rat sinus lining cells.

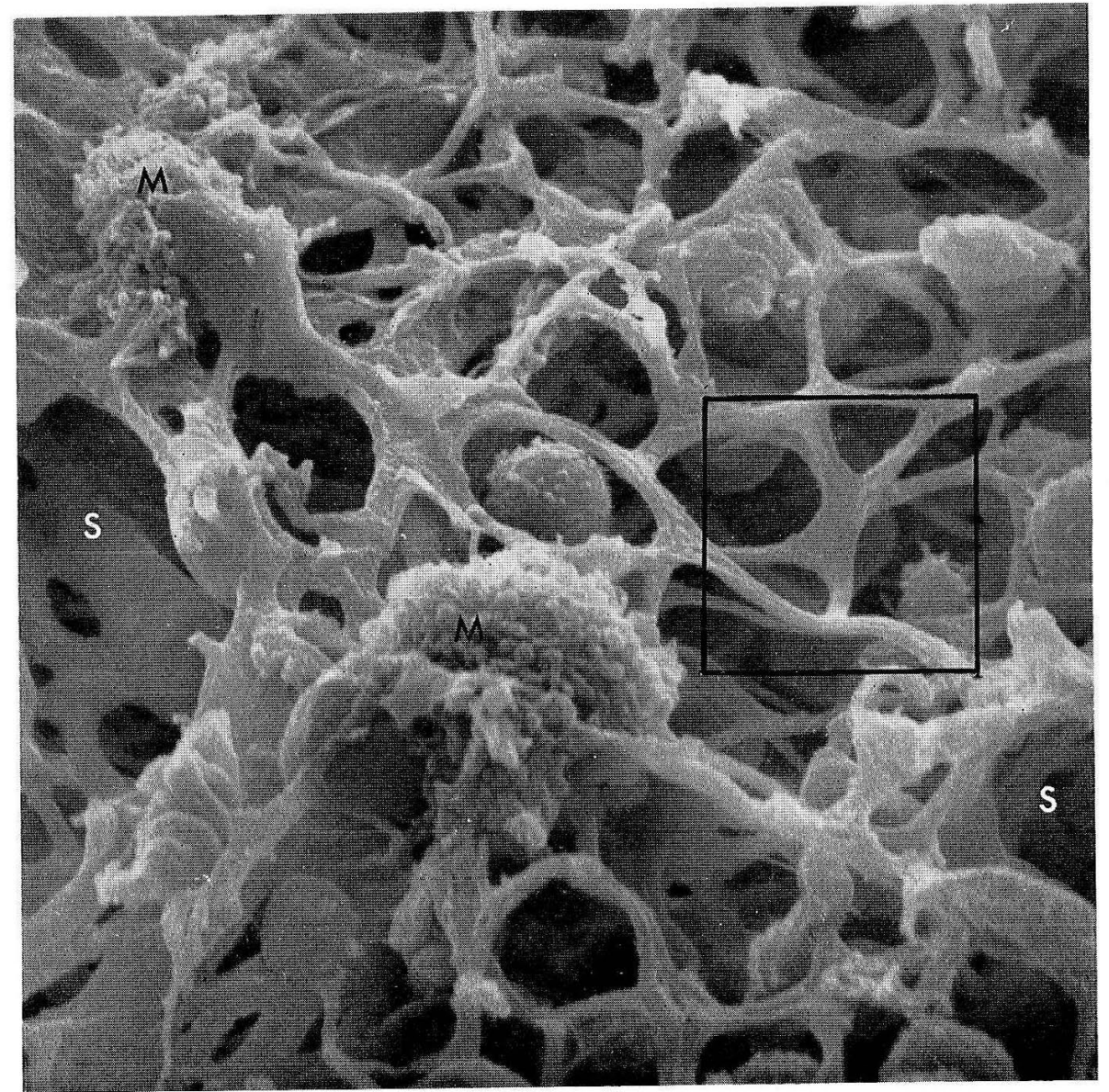

Fig. 6. A scanning electron micrograph of a cut surface of the cord in the dog. The slender cytoplasmic processes of the reticular cells form a network with stellate nodes. In the spaces of this net are seen bristling large macrophages $(M)$ fixed by the reticulum, and some small cells of probable free and wandering nature. $\times 3,600$

Cut profiles of the reticular cells in a polygonal shape and their thin cytoplasmic processes were dispersed in the lucent background (Fig. 13, 15). The cytoplasm of the reticular cell was thin around its round nucleus with dense chromatin, but contained many flattened sacks of granular endoplasmic reticulum. Rarely seen were inclusion granules. The general structure of the reticular cells closely resembled that 
of the fibroblasts as shown by Pictet and his co-workers (1969) and by Burke and Simon (1970).

Strands of the basement membrane-like structure, associated with or without a fasicle of collagenous fibrils, were seen in the recesses of the reticular cells or on their free surface (Fig. 13, 14, 15). On the latter occasion the opposite side of the strand was covered by another cytoplasmic piece of reticular cell.

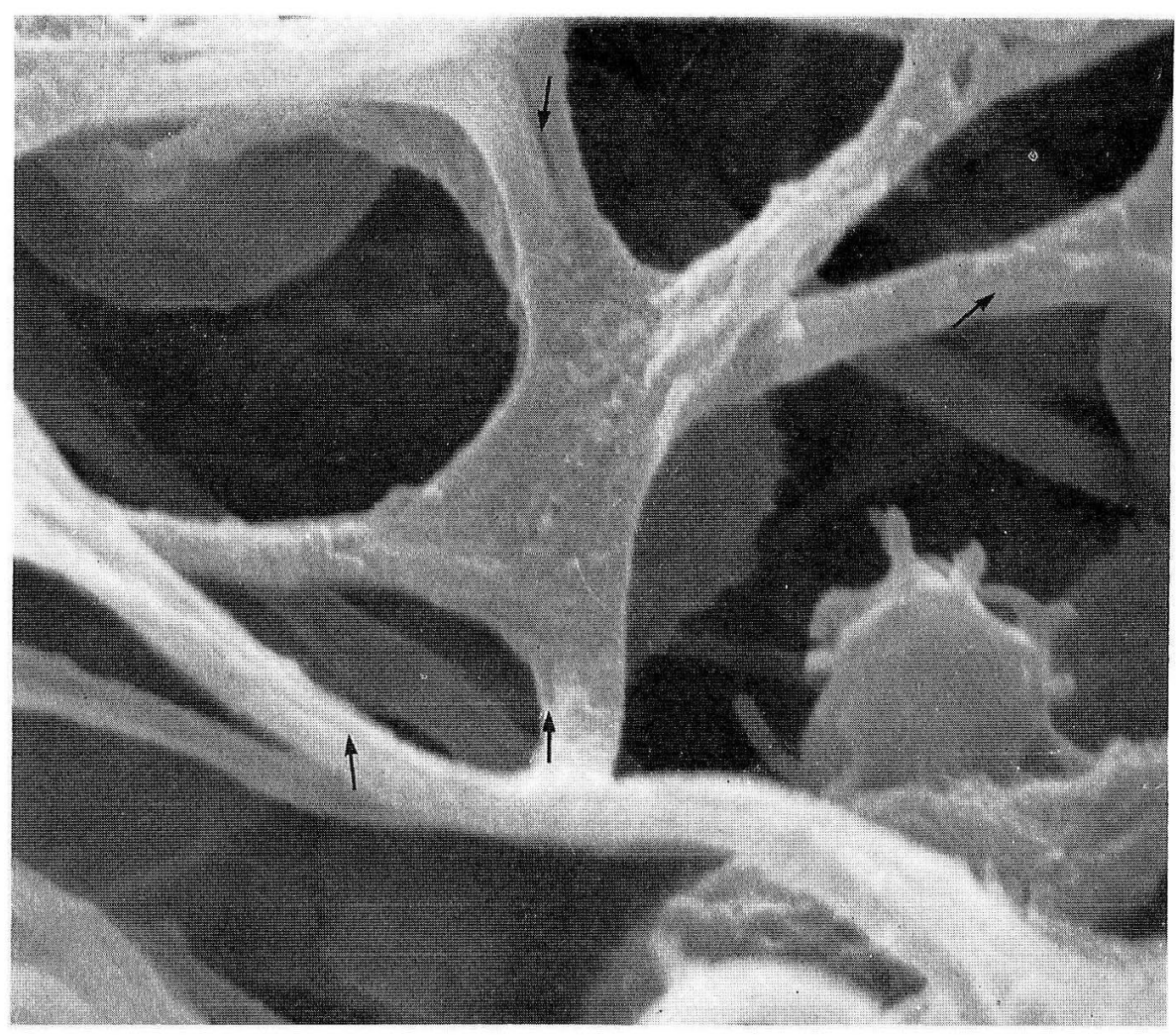

Fig. 7. A close-up view of the reticulum in the box of Figure 6. Besides some tiny microprojections, wrinkle-like streaks (arrows) are seen extending longitudinally on the cytoplasmic threads of the reticular cells. $\times 14,000$

Besides some blood cells many macrophages were observed in the cord space (Fig. 14, 15). The macrophages which possibly correspond to the so-called splenocytes (Kiyono, 1920; Aschoff, 1924; Akazaki, 1957) were large, spherical cells with a bristled surface as Thomss (1967) and Picteт and his co-workers (1969) observed in the perfused spleens. In the cytoplasm of the macrophages a round or lobulated nucleus with dense chromatin masses was situated centrally. The cytoplasmic matrix was usually electron-lucent. Membranous organelles, such as a set of Golgi apparatus, some round mitochondria, and granular or agranular endoplasmic reticulum were well developed. Flattened sacks of granular endoplasmic reticulum were usually situated in a lamellar arrangement in the peripheral zone of the cell. Among these cytoplasmic organelles were mixed some lysosomal granules or phagocytosed debris 
of erythrocytes.

The cell surface of the macrophage was represented by numerous cytoplasmic processes which contained none of the membranous elements mentioned above. Two types of cells were distinguished by the forms of their processes: cells densely covered with round-headed or bubble-like processes (Fig. 14), and cells with thin, foliate processes (Fig. 15). The former type cells were found more frequently than the latter. Some intermediate cells were found showing features of both types.

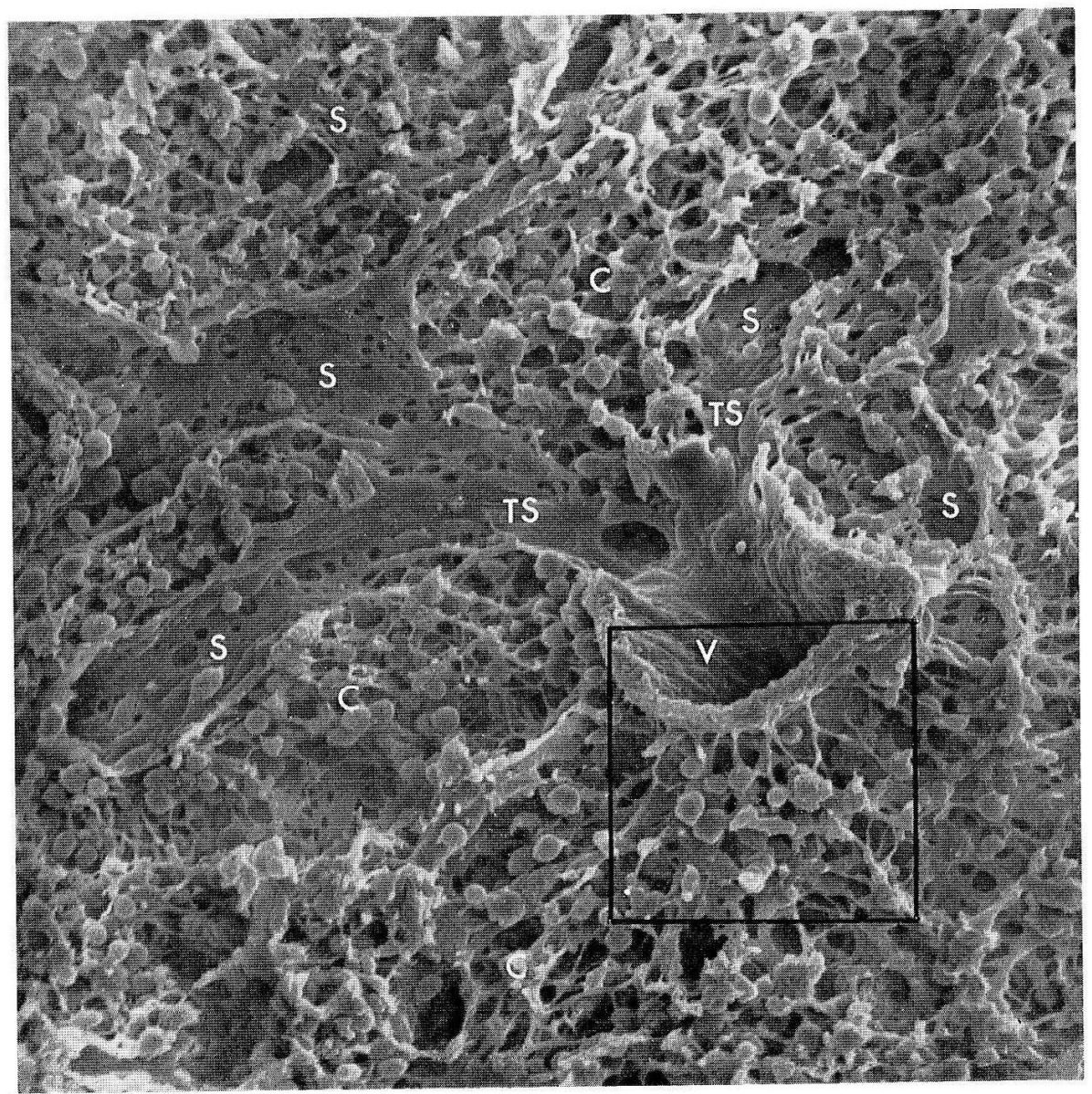

Fig. 8. A low-power scanning electron micrograph of the red pulp around a trabecular vein $(V)$ in the dog splecn. Sinuses $(S)$ anastomosed to each other are continuous to a vein. At the transiting portion of the sinuses $(T S)$ to the vein, the lining cells with spindle-shaped nuclei are in close contact with each other and no opening is seen. $C$ cord. $\times 600$

A morphological correlation was found in the macrophage between the form of the processes and the amount of cytoplasmic granules. The cells with round-headed processes possessed ample cytoplasm and lysosomes with fine granular content (Fig. 14), while the cells with foliate processes were usually filled with large dense granules and large cell debris (Fig. 15). 
At certain sites of the cell surface the macrophages were attached by the reticular fibers mentioned above (Fig. 14, 15). The cut profiles of the reticular fibers were usually seen at the base of the cell processes and wcre accompanied by a thin cytoplasmic piece of reticular cell. At this point the reticular fibers were sandwiched by the macrophage and reticular cell.

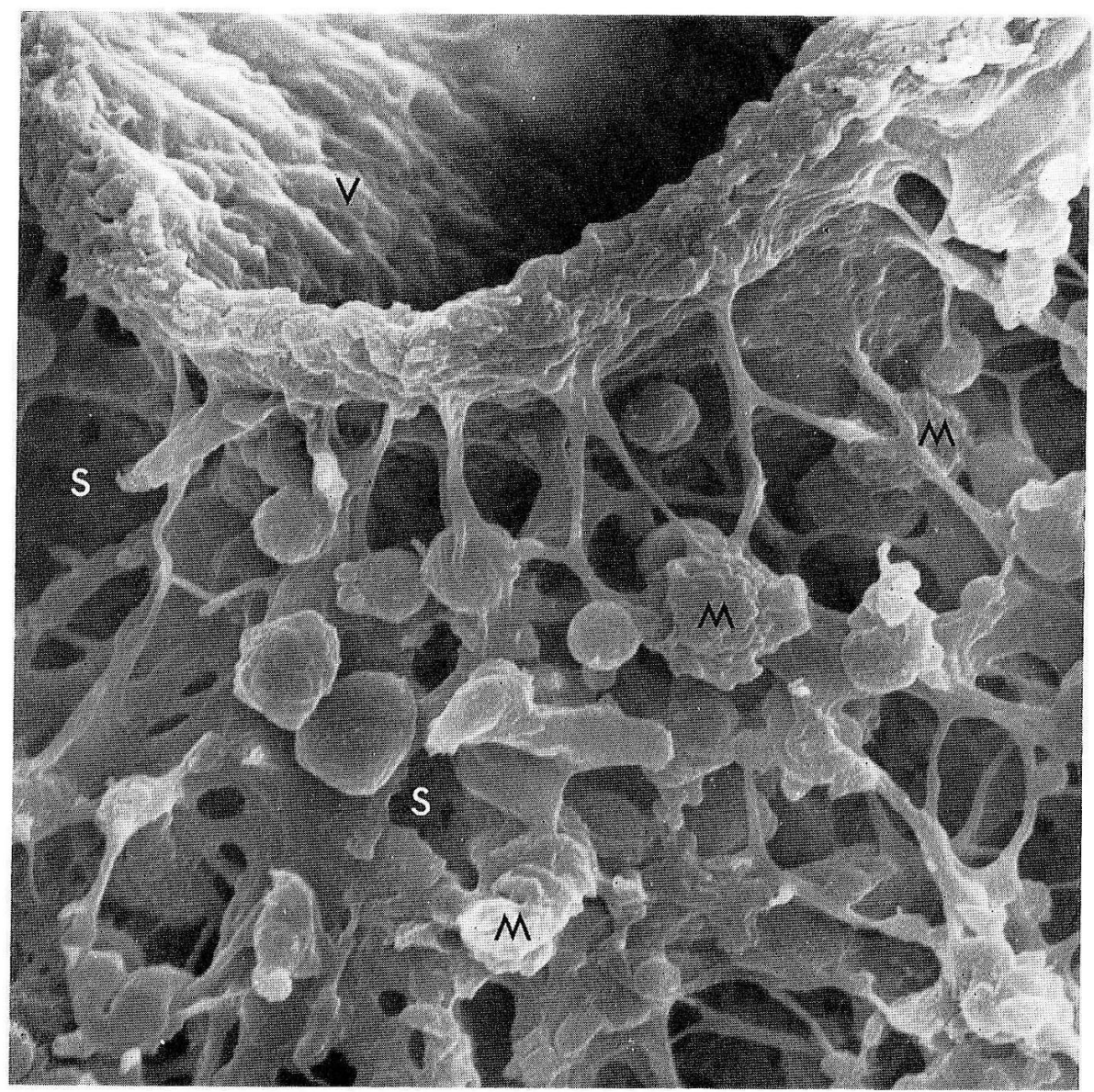

Fig. 9. A closer view of the reticular tissue in the box in Figure 8. The cordal space around the vein $(V)$ is crossed by reticular cell processes, which are attached to the vein wall with a sole-like expansion of the cytoplasm. Some large macrophages $(M)$ with an undulated surface are seen fixed by the reticulum. Smaller spherical cells with smoother surfaces are found in the mesh of the reticular cells. $S$ sinus. $\times 2,400$

Smaller round cells $(4-7 \mu)$ of probable free type were found occasionally in the cordal spaces. Besides leucocytes of different types, plasma cells occurred relatively frequently (Fig. 13). 


\section{Discussion}

The present SEM observations of the dog and rat spleen clearly differentiate three main cellular components of the splenic red pulp: the sinus lining cells, cord reticular cells and macrophages (splenocytes).

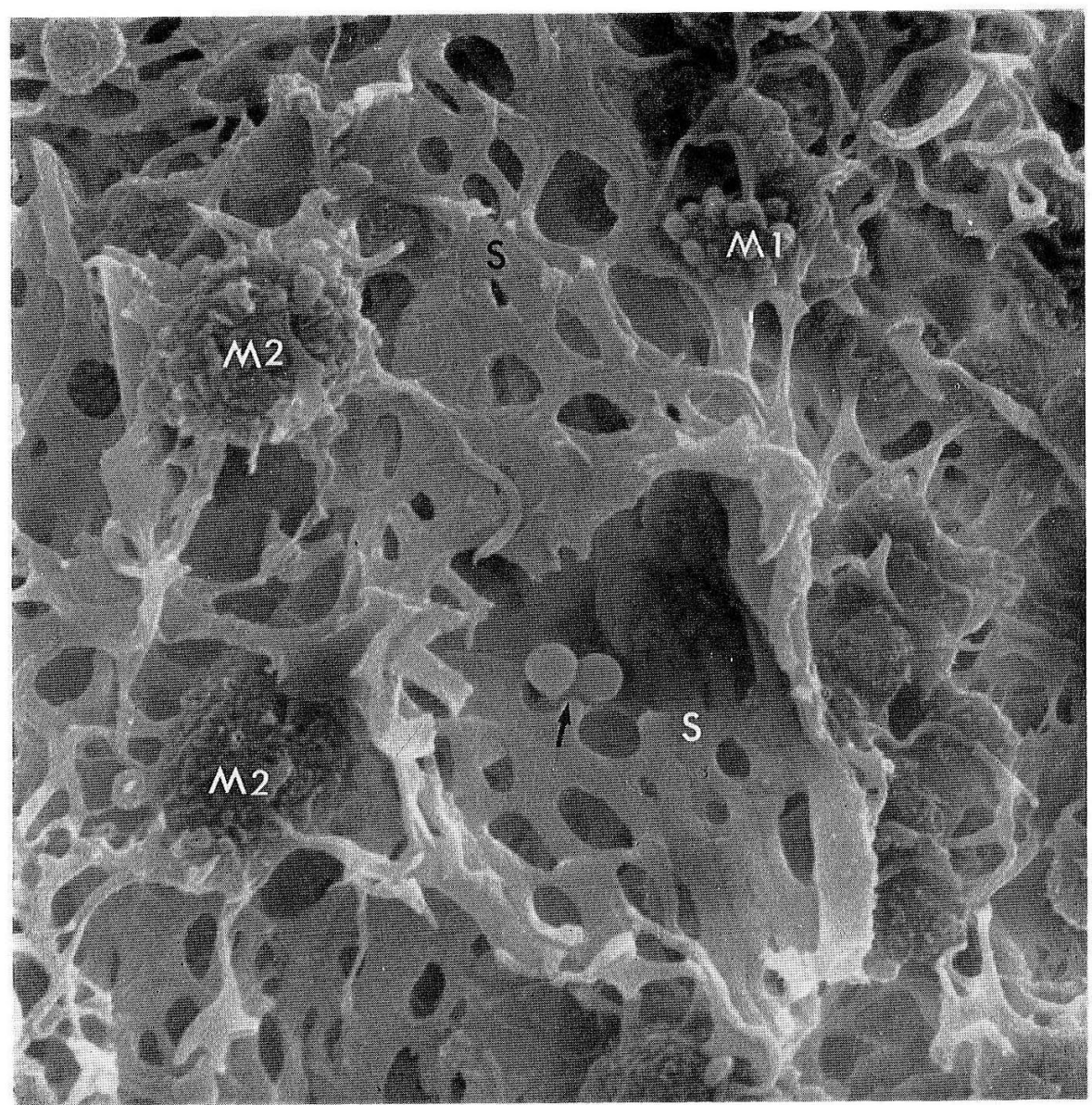

Fig. 10. A scanning electron micrograph of cordal elements surrounding a sinus $(S)$ in the rat spleen. Two types of macrophages are seen: a cell with bubble-like processes $\left(M_{1}\right)$ and others $\left(M_{2}\right)$ covered with thinned, foliate processes. The two round bodies indicated by the arrow may possibly represent a red blood cell hanging on a thread of the sinus lattice. Note also the thread-like processes of the reticular cells clinging on the outer side of the sinus (black S). $\times 2,400$

As was pointed out in our previous paper (Mryoshi, Fujita and Tokunaga, 1970), there have been controversial opinions on the structural and functional independence of the sinus lining cells and the cord reticular cells. Galindo and FreEman (1963), for instance, recognized no difference between the sinus and cord channels as they compared their cellular elements under the TEM. RoBERTs and LATTA (1964) suggested that the sinus and cords may dynamically be changing from one to another. 
The scanning electron micrographs in our present and previous papers reveal so distinct and constant differentiation in the structure of the sinus and cord that it is unlikely that the cells are identical or transient. We thus believe that the sinus lining cells and cord reticular cells are independent cell types both in structure and function.

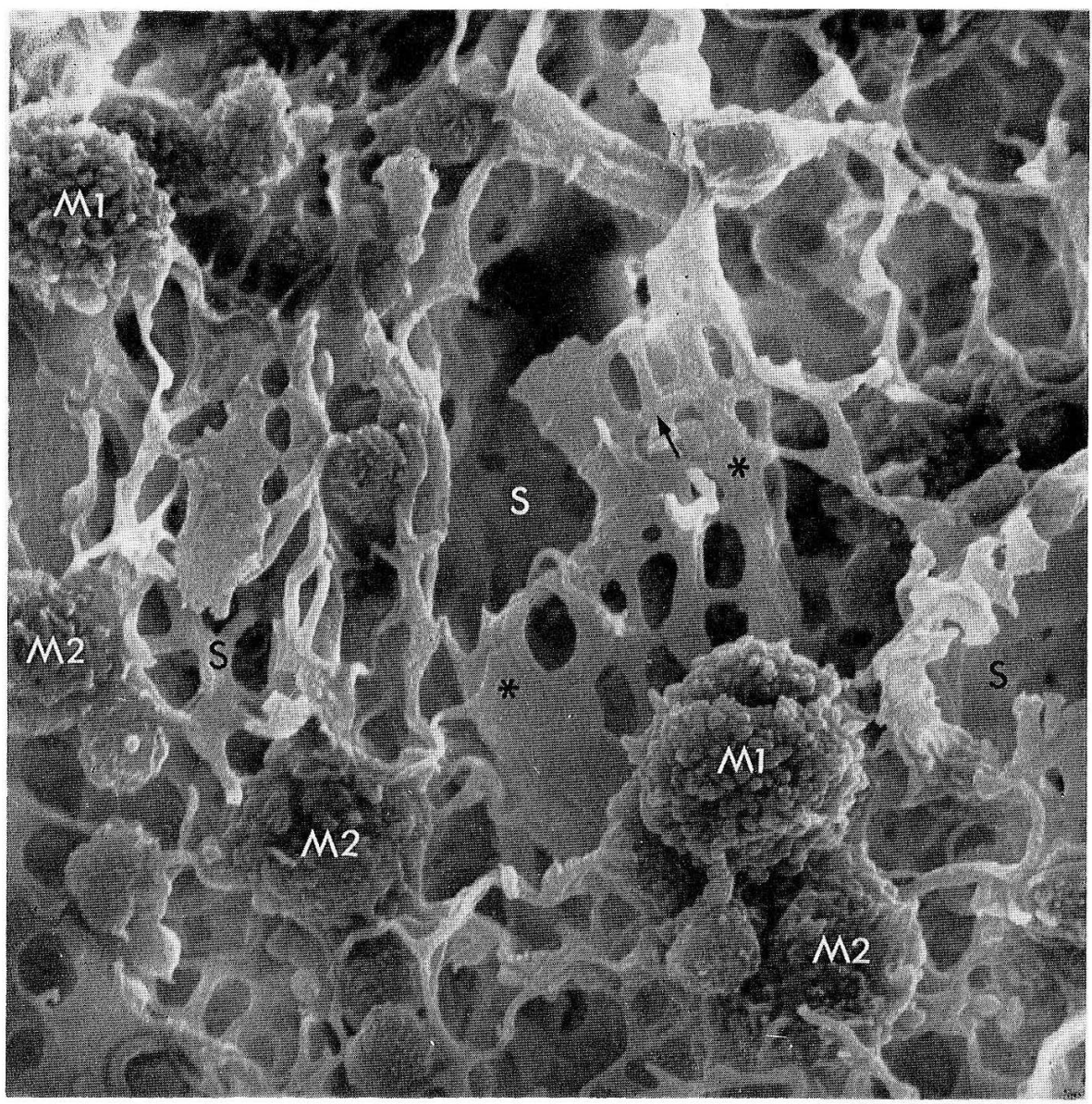

Fig. 11. A scanning electron micrograph of the reverse side of a sinus (white $S$ ) in the rat spleen. On the external surface of the sinus is attached thin, sole-like reticular cell cytoplasm (*) and its thread-like processes (arrows). In the Billroth cords there are seen two types of large, round macrophages. One is densely covered with round-headed processes $\left(M_{1}\right)$ and the other processes undulating and foliate processes $\left(M_{2}\right)$. Small, round cells of probable free type are also seen, $\quad \times 2,400$

The round cells in the red pulp which were identified as macrophages were first clearly visualized by PiстEт and his co-workers (1969) in the perfused spleen under the TEM. Although some early light microscopists distinguished large, round cells with vigorous phagocytosis under the name of splenocytes (Kiyono, 1920; Aschoff, 1924), descrimination of this cell type from cordal reticular cells and from wandering 
cells of smaller size has been either unclear or ignored by most of the later authors (see e.g. the textbook by Bloom and Fawcet, 1968).

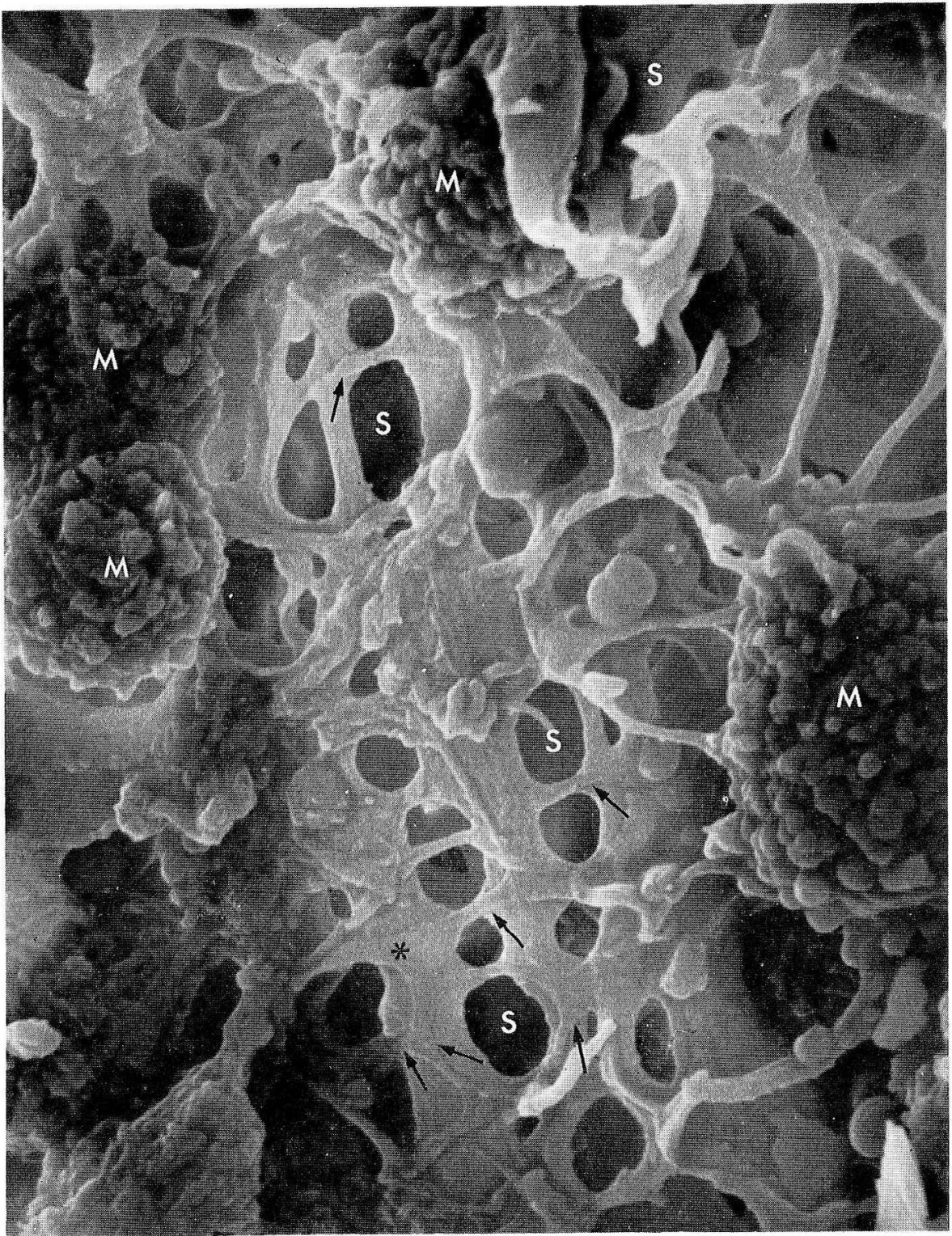

Fig. 12. A scanning electron micrograph of the external surface of a sinus $(S)$ in the rat. Membranous (*) and thread-like processes (arrows) of reticular cells are flatly attached to and extended alongside the sinus wall. Many threads communicate these structures with the cordal reticulum. It is clearly scen that every side bridge of the lining cells of the sinus is backed by a reticular cell process. Macrophages $(M)$ densely covered with bubble-like processes are anchored by the threads of reticular cells. $\times 4,500$ 


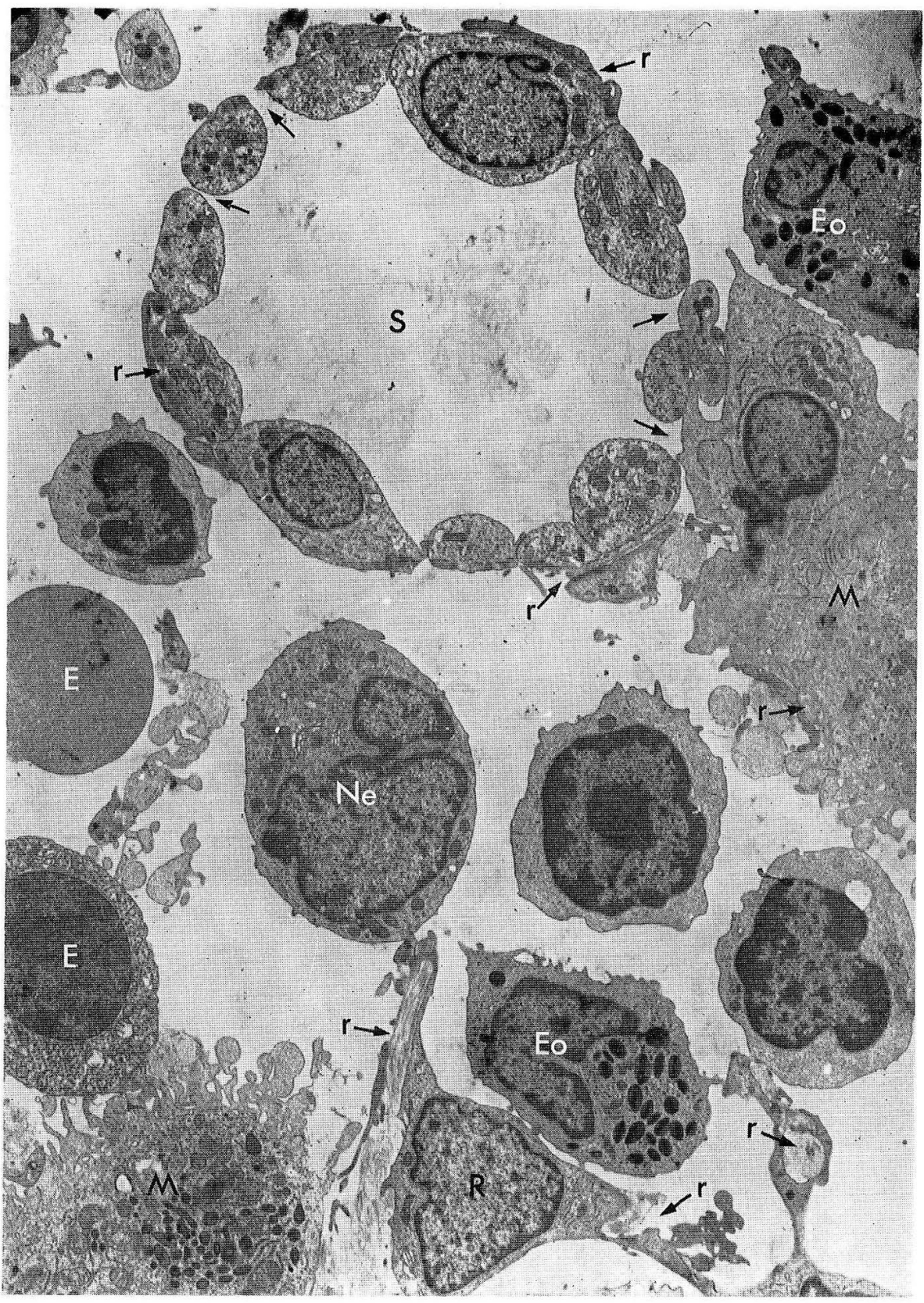

Fig. 13. A transmission electron micrograph of the red pulp in the rat. A sinus (S) crossly cut is lined by lining cells. Although some cells are in close contact with each other, some others show interstices between their lateral sides (arrows). Reticular fibers $(r)$ are applied to the basal cytoplasm of the lining cells and on the reticular cells $(R)$, and the opposite side of the fibers is covered by a thin cytoplasmic extension of reticular cell. In the cord space are dispersed some macrophages $(M)$ and blood cells such as erythroid cells $(E)$, neutrophil $(N e)$ and eosinophil (Eo) leucocytes, and lymphocytes. $\times 8,700$ 
We will now advance to the discussion of the stereo-fine structure of the three cellular elements of the splenic pulp.

\section{Sinus lining cells}

The present findings on the lattice structure of the sinus lining cells in dog and rat spleens essentially correspond to that in the rabbit spleen (Mryoshi, Fujita and TokunAga, 1970). However, some variations in the size of the framing components and openings in the lattice were noticed among these animals.

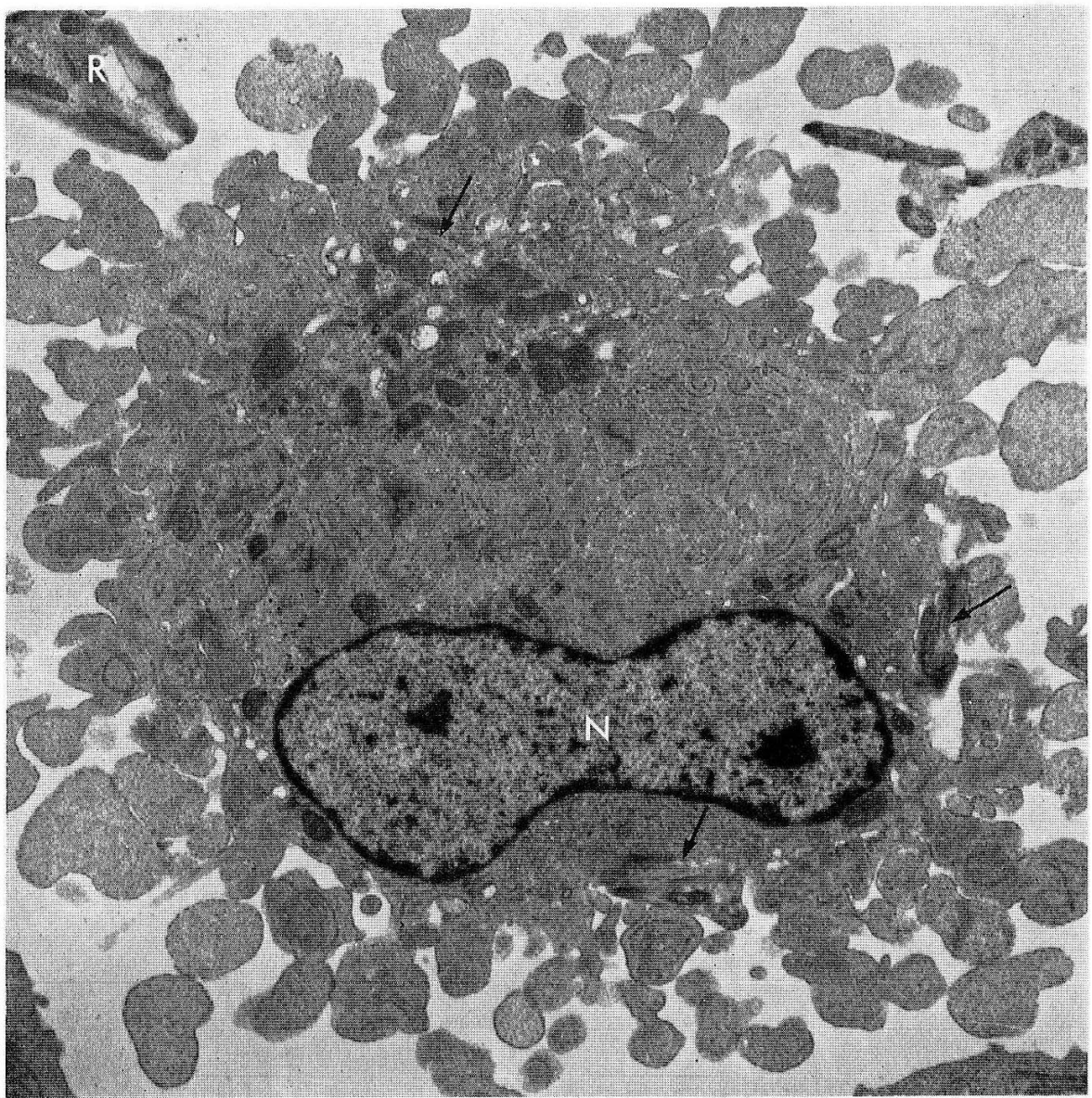

Fig. 14. A transmission electron micrograph of a macrophage in the rat covered by numcrous bubble-like cytoplasmic processes. The cytoplasm contains many cisterns of granular reticulum, and small mitochondria. At the base of the cytoplasmic processes of the cell, three profiles of the reticular fibcrs (arrows) are seen attached to the cell surface. $R$ reticular cell process. $\times 12,000$

In the rabbit the rectangular pattern of the sinus lattice was clear and the longitudinal element represented by the rod cell body was mightier than the transverse one represented by the side processes of the rod cell. The sinus lattice of the dog is 
net-like in appearance because of the similar thickness of the rods and their side bridges and because of the occurrence of large openings. The lattice in the rat appears to be an intermediate type between that of the dog and the rabbit. A great variety in the thickness of the rod cells seems characteristic of the sinus in the rat. Openings of remarkably large size occur frequently and it is likely that in the rat more amount of blood than in other animals may be exchanged between the spaces of the sinus and the cords of Billroth which is especially developed in this species.

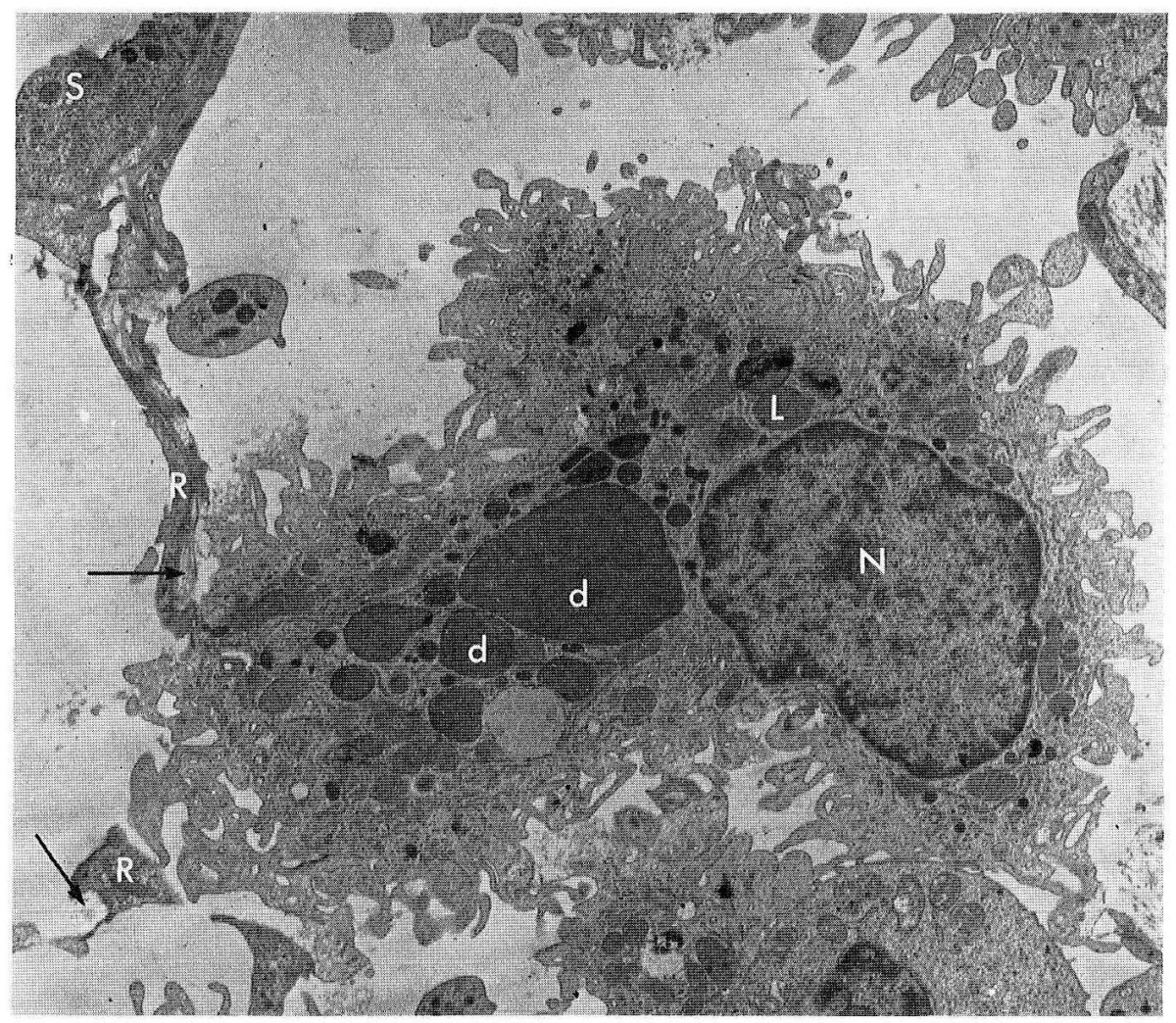

Fig. 15. A transmission electron micrograph of a macrophage in the rat covered with foliate cytoplasmic processes. The cytoplasm contains many fine granular lysosomes $(L)$ and debris of phagocytozed erythrocytes $(d)$. A reticular cell process $(R)$ is seen extending from the sinus wall $(S)$ to the macrophage. The arrows indicate reticular fibers accompanied by reticular cell. $\times 9,000$

The phagocytotic activity of the sinus lining cells has been proved light and electron microscopically by many investigators (TISCHENDORF, 1969; CARR, 1970 for reference). WeIss $(1957,1963)$ firstly showed a large number of pinocytotic vesicles and some inclusion bodies in the sinus lining cells of mammals including the rabbit and rat. The findings were later proved experimentally by administration of tracers such as thorotrast and ferritin (WEIss, 1963, 1964; CARR, 1968 and others).

The findings of our previous study in the rabbit (1970) and of the present observation in the rat and dog may suggest that the lining cells in the dog and rat 
function more simply as a mechanical lining of the sinus wall than those in the rabbit, because prominent microvilli or caveolae on the cell surface numerously seen in the rabbit are not recognized in these animals. The phagocytotic activity in the spleen of these animals, in any case, is thought to be achieved maily by the cordal reticular cells and specialized macrophages. The TEM finding in the present study indicates that, at least in the rat under normal conditions, the phagocytotic activity of the sinus lining cells, if any, is very small. It is added that, in the dog, many of the arterial capillaries are sheathed by highly phagocytic adventitial cells which are specialized reticular cells (WEIss, 1962; ZwILLENBERG and ZWILLENBERG, 1962; CARR, 1970).

\section{Reticular cells and reticular fibers}

As mentioned in the Introduction, it is known that the reticular fibers which are revealed under the TEM as thin strands of a basement membrane-like material are invested by the thin cytoplasm of the reticular cells. This relation was confirmed by the present study, although a reticular fiber was often seen dislocated from the cytoplasmic recess - a probable artifact caused by air-drying. Longitudinal streaks revealed by the SEM on the reticular cells in the cord may reflect the invagination and the lips of the reticular cell cytoplasm investing the reticulin fibers.

As seen in many review monographs (HARTMAnN, 1930; Tischendorf, 1969) and textbooks (for example, Bargmann, 1964; Togari, 1964; Bloom and Fawcett, 1968 and others), most of the morphological studies of the fine structure of the sinus wall have been focused on the relationship between the sinus lining cells and the ring fibers, the reticular fibers transversely surrounding the sinus. The pioneer TEM observations by WEISS $(1957,1963)$ and STOECKENIUS (1958) revealed the fibers as fenestrated basement membrane interposed between the sinus lining cells and the cord reticular cells (see also Thomas, 1967). However, the TEM study using fragmental, two-dimensional sections have been far from viasualizing the extension of the ring fibers. Light microscope techniques have been much more advantageous for this purpose.

In our previous SEM observations in the rabbit (Mryoshi, Fujita and Tokunaga, 1970), clear visualization was not attained concerning the relation of the reticular processes to the sinus lining cells. Only a brief description explained that the liplike ends of the reticular cell processes backed the lining cells.

The SEM observations in the present study clearly demonstrated the relation of the reticular cell network to the sinus wall. On the sinus wall most of the cytoplasmic threads from the reticular cells were extended transversely to the sinus lining cells and backed every side bridge of the lattice structure. The extension of the cytoplasmic processes of the reticular cells matches that of the ring fibers (Ковотн, 1939; SNook, 1950 and others). The present SEM finding leads to the conclusion that the reticular ring fibers are situated along the transverse components of the sinus lattice. From the TEM findings it is probable that reticular fibers occur only at the mutual contact portions between the sinus lining cell and the reticular cell as postulated in previous studies (Thomas, 1967). The latter cell seems necessary in the spleen for the formation of the fibers. 


\title{
3. Macrophages
}

Some of the previous TEM studies (Moore et al., 1964; Thomas, 1967; Pictet et al., 1969; and others) indicated the presence of many lysosomal granules and the debris of ingested cells in large, round cells of the red pulp. This type of cell, as mentioned above, corresponds to the splenocyte or the fixed macrophage in the spleen known by early light microscopists (Kiyono, 1920; Aschoff, 1924). Though the surface fine structure of the cells has recently been studied in sections of the perfused spleen by PICTET and his associates (1969), no description has been made of the morphological correlation between the external structure and the phagocytotic activity or the internal structure of the cells.

On the other hand, some information has been accumulating about the surface structure of the macrophage in general by means of the SEM. The cells studied, however, have been free type macrophages from peritoneal fluid (CARR et al., 1969; CARR, 1970; Hope and FrIEND, 1969) or from pulmonary exudate (Holma, 1969). No SEM observation of macrophages as they are in the tissue of any organ seems to have been perfomed.

The present SEM and TEM study clearly demonstrated the external structure of the macrophage in the mesh of the cordal reticulum. It was further revealed that in the cells covered mainly with round-headed processes the fine granular lysosomes and other membranous cell organelles were more numerous than large heterophagosomes or ingested cell debris, while the relation was inverse in the cells covered mainly with membranous processes. This description may be supported by CARR's (1968) experiment on peritoneal macrophages. On the stimulated macrophages he observed the elongation of the cytoplasmic processes and an increase in the number of cellular inclusion bodies.

In their TEM study of the perfused rat spleen, PICTET et al. (1969) did not see the attachment of the macrophage to the reticular fiber and ascribed the attachment described previously to an artifact caused by immersion fixation. In the present study using spleens which were completely washed with saline and perfused with fixative to preserve the spaces in the splenic cords and to eliminate all the free cells, the macrophages under the SEM were anchored by some threads of the cytoplasmic processes of reticular cells. The TEM observation further confirmed that the cells were attached to reticular fibers which intervened between the cell and the reticular cell process. Thus, the present combined SEM and TEM study unequivocally indicates that the round phagocytotic cells in the splenic cords are macrophages of fixed type and remain in the tissue as the third cellular element of the red pulp when all the free cells have been washed out.

\section{赤脾剈道の立体微細構造. 走查および透過電子鏡によるイヌと ラットの脾蔵の観察}

\author{
三 好 萬佐行と藤 田 恒 夫 \\ イヌとラットの脾臓に 脾動脈からリンゲル液を潅流して 血液を充分に洗いだし，続 \\ いて緩衝したグルタールアルデヒド液を注入して固定した. この脾臓の赤脾骾の割面を
}


走査電子鏡で観察し，また同じ標本の樹脂包埋組織切片を透過電子鏡で検索した。

1. イヌとラットの脾洞の壁は 孔あき格子構造で, 杆状細胞とその細胞突起からな り，ウサギで観察した所見 (MiyoshI, Fujita and TokunAGA, 1970) と同じであったが, 若干の明瞭な動物差が認められた。

2. 脾洞と脾柱静脈の間に 孔のない移行部静脈洞が分化していた.

3. 脾索は細網細胞の突起で作られた 迷路状の網目であった. 切片を透過電子鏡で見 ると，細網細胞の紐状の突起に抱きこまれ，あるいははさまれて走る細網線維が認めら れた。

4. 細網細胞は静脈や脾洞の壁に突起をのぼし，足底状に細胞質を広げて固着してい た。

5. 脾洞の外表面では，この細胞質から出る細い突起が 主として杆状細胞の方向とは 直角にのびていた. 杆状細胞のひとつの側突起はひとつの細網細胞突起で裏打ちされて いた，両細胞要素間に細網線維 (たが線維) がはさみこまれていることは, 切片の透過電 子鏡観察によって知られる。

6. 脾索細網の網目には 大きい球状の大食細胞が, 細網線維によってからめられて いた. この大食細胞の一型は 泡状の突起に被われる細胞で, 他の一型は葉状の突起をも つものであった.

7. 透過電子鏡で見ると前者の型ほ微細顆粒状のライソゾームを持ち, 後者の型の細 胞は粗大顆粒状のライソゾームや 食べこをれた大きな細胞破片を持っていた。

\section{References}

Akazaki, K.: A continued report on reticulo-endothelial system and the changes thereof caused by inflammatory stimulation. Tohoku J. exp. Med. 66: 293-306 (1957).

Aschoff, L.: Das reticulo-endothelial System. Ergebn. inn. Med. 26: 1-118 (1924).

Bargmann, W.: Histologie und mikroskopische Anatomie des Menschen. 5 Aufl., Stuttgart, Georg Thieme, 1964. (p. 288).

Bloom, W. and W. Fawcett: A textbook of histology. 9th ed., Philadelphia-London-Toronto, W. B. Saunders, 1968. (p. 403).

Burke, J. S. and G. T. Simon: Electron microscopy of the spleen. 1. Anatomy and microcirculation. Amer. J. Pathol. 58: 127-155 (1970).

Carr, I.: Lysosome formation and surface changes in stimulated peritoneal cells. Z. Zellforsch. 89: 328-354 (1968). 348 (1970).

Carr, I., J. A. Clarke and A. J. Salsbury: The surface structure of mouse peritoneal cells: a study with the scanning electron microscope. J. Microsc. (Oxford) 89: 105-111 (1969).

Galindo, B. and J. A. Freeman: Fine structure of splenic pulp. Anat. Rec. 147: 25-41 (1963).

Hartmann, A.: Die Milz. In: Möllendorffs Handbuch der mikroskopischen Anatomie des Menschen. VI/1. Berlin, Springer Verlag, 1930. (p. 397).

Holma, B.: Scanning electron microscopic observation of particles deposited in the lung. Arch. environ. Health. 18: 330-339 (1969).

Hope, J. and J. V. Friend: Preliminary scanning electron microscopic observations on the effect of silica dusts on cultured macrophages. Micron 1: 310-324 (1969). 
Kiyono, K.: Studies on the vital staining (Japanese). 2nd ed., Tokyo, Nankodo, 1920.

Knisely, M. H.: Spleen studies. 1. Microscopic observations of the circulatory system of living unstimulated mammalian spleens. Anat. Rec. 65: 23-50 (1936).

Koboth, J.: Über die Gitterfasergerüst der roten Milzpulpa. Ziegler Beitr. pathol. Anat. 103: 11-29 (1939).

Luft, J. H.: Improvements in epoxy resin embedding methods. J. biophys. biochem. Cytol. 9: 409414 (1961).

Millonig, G.: A modified procedure for lead staining of thin sections. J. biophys. biochem. Cytol. 11: 736-739 (1961).

Miyoshi, M., T. Fujita and J. Tokunaga: The red pulp of the rabbit spleen studied under the scanning electron microscope. Arch. histol jap. 32: 289-306 (1970).

Mollier, S.: Über den Bau der capillaren Milzvenen (Milzsinus). Eine kritische Studie und eigene Beobachtungen. Arch. mikrosk. Anat. 76: 608-657 (1911).

Moore, R. D., V. R. Mumaw and M. D. Schoenberg: The structure of the spleen and its functional implications. Exp. mol. Pathol. 3: 31-51 (1964).

Ohta, Y.: Cubical anatomy of several ducts and vessels by injection method of acrylic resin. II. On the vascular system of the spleen in some mammals. Okajimas Folia anat. jap. 3: 13-41 (1957).

Pictet, R., L. Orci, W. G. Forssmann and L. Girardier: An electron microscope study of the perfusion fixed spleen. I. The splenic circulation and the RES concept. Z. Zellforsch. 96: 372-399 (1969).

Roberts, D. K. and J. S. Latta: Electron microscopic studies on the red pulp of the rabbit spleen. Anat. Rec. 148: 81-101 (1964).

Snook, T.: Comparative study of the vascular arrangement in mammalian spleens. Amer. J. Anat. 87: 31-78 (1950).

Stoeckenius, W.: Elektronenmikroskopische Untersuchungen am Retikulum der Milz. Verh. Deut. Ges. Pathol. 42: 351-353 (1958).

Stöhr, Ph., W. v. Möllendorff und K. Görttler: Lehrbuch der Histologie und mikroskopischen Anatomie des Menschen. 29. Aufl., Jena, Gustav Fischer, 1963. (p. 252).

Thomas, C. E.: An electron- and light-microscope study of sinus structure in perfused rabbit and dog spleens. Amer. J. Anat. 120: 527-552 (1967).

Tischendorf, F.: Die Milz. In: (ed. by) W. Bargmann: Möllendorffs Handbuch der mikroskopischen Anatomie des Menschen. VI/6. Berlin-Heidelberg-New York, Springer Verlag, 1969.

Togari, K.: Histology (Japanese). 7th ed., Tokyo, Nanzando, 1954. (p. 113).

Weiss, L.: A study of the structure of splenic sinuses in man and in the albino rat, with the light microscope and the electron microscope. J. biophys. biochem. Cytol. 3: 599-610 (1957).

- : The structure of the fine splenic arterial vessels in relationship to hemoconcentration and red cell destruction. Amer. J. Anat. 111: 131-175 (1962).

: The structure of intermediate vascular pathways in the spleen of rabbits. Amer. J. Anat. 113: 51-91 (1963).

-: The white pulp of the spleen. The relationships of arterial vessels, reticulum and free cells in the periarterial lymphatic sheath. Bull. Johns Hopkins Hosp. 115: 99-173 (1964).

Zwillenberg, L. O. und H. H. Zwillenberg: Elektronenmikroskopische Beobachtungen an der Hülsenarteriolen in der Milz des Hundes. Experientia 18: 136-137 (1962).

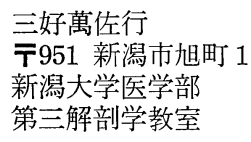

三好萬佐行

新潟大学医学部

第三解剖学教室
Dr. Masayuki Mryoshi

Department of Anatomy

Niigata University School of Medicine

951 Niigata, Japan 